\title{
Front Matter: Volume 6974
}

"Front Matter: Volume 6974," Proc. SPIE 6974, Multisensor, Multisource Information Fusion: Architectures, Algorithms, and Applications 2008, 697401 (17 March 2008); doi: 10.1117/12.795159

SDIE Event: SPIE Defense and Security Symposium, 2008, Orlando, Florida, SPIE. United States 


\section{PROCEEDINGS OF SPIE}

\section{Multisensor, Multisource Information Fusion: Architectures, Algorithms, and Applications 2008}

Belur V. Dasarathy

Editor

18-20 March 2008

Orlando, Florida, USA

Sponsored and Published by

SPIE

Volume 6974 
The papers included in this volume were part of the technical conference cited on the cover and title page. Papers were selected and subject to review by the editors and conference program committee. Some conference presentations may not be available for publication. The papers published in these proceedings reflect the work and thoughts of the authors and are published herein as submitted. The publisher is not responsible for the validity of the information or for any outcomes resulting from reliance thereon.

Please use the following format to cite material from this book:

Author(s), "Title of Paper," in Multisensor, Multisource Information Fusion: Architectures, Algorithms, and Applications 2008, edited by Belur V. Dasarathy, Proceedings of SPIE Vol. 6974 (SPIE, Bellingham, WA, 2008) Article CID Number.

ISSN 0277-786X

ISBN 9780819471659

Published by

SPIE

P.O. Box 10, Bellingham, Washington $98227-0010$ USA

Telephone +1 3606763290 (Pacific Time) · Fax +1 3606471445

SPIE.org

Copyright (c) 2008, Society of Photo-Optical Instrumentation Engineers

Copying of material in this book for internal or personal use, or for the internal or personal use of specific clients, beyond the fair use provisions granted by the U.S. Copyright Law is authorized by SPIE subject to payment of copying fees. The Transactional Reporting Service base fee for this volume is $\$ 18.00$ per article (or portion thereof), which should be paid directly to the Copyright Clearance Center (CCC), 222 Rosewood Drive, Danvers, MA 01923. Payment may also be made electronically through CCC Online at copyright.com. Other copying for republication, resale, advertising or promotion, or any form of systematic or multiple reproduction of any material in this book is prohibited except with permission in writing from the publisher. The CCC fee code is 0277-786X/08/\$18.00.

Printed in the United States of America.

Publication of record for individual papers is online in the SPIE Digital Library.

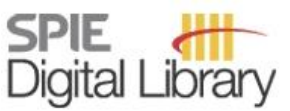

SPIEDigitalLibrary.org

Paper Numbering: Proceedings of SPIE follow an e-First publication model, with papers published first online and then in print and on CD-ROM. Papers are published as they are submitted and meet publication criteria. A unique, consistent, permanent citation identifier (CID) number is assigned to each article at the time of the first publication. Utilization of CIDs allows articles to be fully citable as soon they are published online, and connects the same identifier to all online, print, and electronic versions of the publication. SPIE uses a six-digit CID article numbering system in which:

- The first four digits correspond to the SPIE volume number.

- The last two digits indicate publication order within the volume using a Base 36 numbering system employing both numerals and letters. These two-number sets start with $00,01,02,03,04,05$, $06,07,08,09,0 \mathrm{~A}, 0 \mathrm{~B} \ldots \mathrm{OZ}$, followed by 10-1Z, 20-2Z, etc.

The CID number appears on each page of the manuscript. The complete citation is used on the first page, and an abbreviated version on subsequent pages. Numbers in the index correspond to the last two digits of the six-digit CID number. 


\section{Contents}

vii Conference Committee
ix Introduction

IMAGE LEVEL ISSUES AND APPLICATIONS

697402 Portable real-time color night vision [6974-01]

A. Toet, M. A. Hogervorst, TNO Human Factors (Netherlands)

697403 Method for applying daytime colors to nighttime imagery in realtime [6974-02]

M. A. Hogervorst, A. Toet, TNO Human Factors (Netherlands)

697404 Advances in image registration and fusion [6974-03]

C. Steer, J. Rogers, M. Smith, J. Heather, M. Bernhardt, D. Hickman, Waterfall Solutions, Ltd. (United Kingdom)

697405 Further exploration of the object-image metric with image registration in mind [6974-04] O. L. Mendoza, G. Arnold, Air Force Research Lab. (USA); P. Stiller, Texas A\&M Univ. (USA)

697406 Fusion of combined stereo and spectral series for obtaining 3D information [6974-05] I. Gheta, M. Mathias, Univ. Karlsruhe (Germany); M. Heizmann, Fraunhofer-Institut für Informations- und Datenverarbeitung IITB (Germany); J. Beyerer, Univ. Karlsruhe (Germany) and Fraunhofer-Institut für Informations- und Datenverarbeitung IITB (Germany)

\section{DETECTION AND CLASSIFICATION}

697407 Multi-class classification fusion using boosting for identifying steganography methods [6974-06]

B. M. Rodriguez, G. L. Peterson, Air Force Institute of Technology (USA)

697408 Comparing discrimination and CFA for selecting tracking features [6974-07]

D. M. Lyons, D. F. Hsu, Fordham Univ. (USA)

697409 Real-time object-based image registration using multilayer perceptron [6974-09]

P. L. Narasimha, Z. Yue, P. Topiwala, FastVDO, Inc. (USA)

6974 OA A heterogeneous sensor network simulation system with integrated terrain data for realtime target detection in 3D space [6974-10]

H. Lin, S. Tanner, J. Rushing, S. Graves, E. Criswell, Univ. of Alabama in Huntsville (USA)

\section{SURVEILLANCE AND TRACKING}

6974 OB Vehicle tracking in UAV video using multi-spectral spatiogram models [6974-11]

N. E. O'Connor, P. Kehoe, C. O'Conaire, A. F. Smeaton, Dublin City Univ. (Ireland) 
6974 OC Dynamic resource management for adaptive distributed information fusion in large volume surveillance [6974-12]

R. Farahbod, U. Glässer, Simon Fraser Univ. (Canada); H. Wehn, MDA Corp. (Canada)

6974 OD Situation-aware BDI agents in support of autonomous intelligence, surveillance, and reconnaissance (ISR) analysis [6974-13]

L. Lewis, G. Jakobson, J. Buford, Altusys Corp. (USA)

$6974 \mathrm{OE}$ A system for testing distributed information fusion applications for maritime surveillance [6974-14]

H. Wehn, J. Happe, MacDonald, Dettwiler and Associates, Ltd. (Canada); A. Guitouni,

P. Valin, É. Bossé, Defence R\&D Canada, Valcartier (Canada)

6974 OF A field demonstration of multi-INT surveillance and data fusion [6974-15]

A. Na, S. Havens, Argon ST (USA)

APPLICATIONS

6974 OG Data and sensor fusion for bistatic applications [6974-21]

A. L. Lee, Walden Univ. (USA)

$6974 \mathrm{OH}$ Smart optical receiver for beamforming and enhancement of field of view in LADAR systems [6974-22]

J. Khoury, Air Force Research Lab. (USA); B. Haji-saeed, Solid State Scientific Corp. (USA);

C. L. Woods, Air Force Research Lab. (USA); J. Kierstead, Solid State Scientific Corp. (USA)

$69740 \mathrm{~J} T$ The use of a multidimensional space for fusion candidate representation in a maritime domain awareness application [6974-18]

E. Lefebvre, Lockheed Martin Canada (Canada); C. Helleur, N. Kashyap, Defence

Research and Development Canada (Canada)

6974 OK A Markov game model for space threat prediction [6974-16]

D. Shen, Intelligent Automation, Inc. (USA); E. Blasch, AFRL/RYAA (USA); G. Chen, DCM Research Resources, LLC (USA); K. Pham, AFRL (USA); J. B. Cruz, Jr., The Ohio State Univ. (USA); T. M. Schuck, Lockheed Martin MS2 (USA)

\section{MISCELLANEOUS TOPICS}

$6974 \mathrm{OL} \quad$ Non-algorithmic information fusion [6974-26]

J. Brander, Interactive Engineering (Australia)

6974 OM About the fusion of default knowledge [6974-27]

É. Grégoire, CRIL CNRS, Univ. d'Artois (France)

6974 ON Advanced algorithms for distributed fusion [6974-28]

A. Gelfand, C. Smith, M. Colony, Decisive Analytics Corp. (USA); C. Bowman, Data Fusion and Neural Networks (USA); R. Pei, T. Huynh, C. Brown, U.S. Army CERDEC Intelligence and Information Warfare Directorate (USA) 
697400 Dynamic adaptive learning for decision-making supporting systems [6974-29]

H. He, Y. Cao, S. Chen, Stevens Institute of Technology (USA); S. Desai, M. E. Hohil, U.S. Army Armament Research, Development and Engineering Center (USA)

6974 OP Distributed multi-sensor fusion [6974-30]

P. Scheffel, R. Fish, R. Knobler, T. Plummer, McQ, Inc. (USA)

\section{POSTER SESSION}

$69740 Q \quad$ Intermediate view reconstruction using adaptive disparity search algorithm for real-time 3D processing [6974-31]

K. Bae, C. Park, Samsung Thales Co., Ltd. (South Korea); E. Kim, Kwangwoon Univ. (South Korea)

6974 OR Automatic extraction of corresponding-points for image registration [6974-32] J.-H. Jung, W.-C. Choi, D.-J. Park, KAIST (South Korea); C.-H. Park, J.-I. Lee, Samsung Thales Co., Ltd. (South Korea)

6974 OS Design of time-pulse coded optoelectronic neuronal elements for nonlinear transformation and integration [6974-33]

V. G. Krasilenko, A. I. Nikolsky, A. A. Lazarev, M. V. Lazareva, Open International Univ. of Human Development (Ukraine)

Author Index 
Downloaded From: https://www.spiedigitallibrary.org/conference-proceedings-of-spie on 26 Apr 2023

Terms of Use: https://www.spiedigitallibrary.org/terms-of-use 


\title{
Conference Committee
}

\author{
Symposium Chair
}

Larry B. Stotts, Defense Advanced Research Projects Agency (USA)

Symposium Cochair

Ray O. Johnson, Lockheed Martin Corporation (USA)

Program Track Chair

Belur V. Dasarathy, Consultant, Information Fusion Technologies (USA)

Conference Chair

Belur V. Dasarathy, Consultant, Information Fusion Technologies (USA)

Program Committee

Sheela V. Belur, The Van Dyke Technology Group, Inc. (USA)

Jerome J. Braun, MIT Lincoln Laboratory (USA)

Nour-Eddin El Faouzi, Institut National de Recherche sur les Transports (France)

Michael Heizmann, Fraunhofer Institute for Information and Data

Processing IITB (Germany)

Mieczyslaw M. Kokar, Northeastern University (USA)

Christopher J. Matheus, VIStology, Inc. (USA)

Damian M. Lyons, Fordham University (USA)

Firooz A. Sadjadi, Lockheed Martin Corporation (USA)

S. Richard F. Sims, U.S. Army Aviation and Missile Research, Development and Engineering Center (USA)

Pierre Valin, Defence Research and Development Canada, Valcartier (Canada)

Shanchieh J. Yang, Rochester Institute of Technology (USA)

\section{Session Chairs}

Image Level Issues and Applications

S. Richard F. Sims, U.S. Army Aviation and Missile Research, Development and Engineering Center (USA)

Michael Heizmann, Fraunhofer-Institut für Informations-und Datenverarbeitung (Germany) 
Detection and Classification

Sheela V. Belur, The Van Dyke Technology Group, Inc. (USA)

Damian M. Lyons, Fordham University (USA)

Surveillance and Tracking

Jerome J. Braun, MIT Lincoln Laboratory (USA)

Shanchieh J. Yang, Rochester Institute of Technology (USA)

Applications

Pierre Valin, Defence Research and Development Canada, Valcartier (Canada)

Nour-Eddin El Faouzi, Institut National de Recherche sur les Transports (France)

Miscellaneous Topics

Jerome J. Braun, MIT Lincoln Laboratory (USA)

Michael Heizmann, Fraunhofer-Institut für Informations-und Datenverarbeitung (Germany)

Performance Evaluation for Impact Assessment System Panel

Panel Moderators

Erik Blasch, Air Force Research Laboratory (USA)

Jerome J. Braun, MIT Lincoln Laboratory (USA)

James Llinas, University at Buffalo (USA)

Robert S. Lynch, Jr., Naval Undersea Warfare Center (USA)

John J. Salerno, Jr., Air Force Research Laboratory (USA)

Shanchieh J. Yang, Rochester Institute of Technology (USA) 


\section{Introduction}

This is our 12th consecutive successful offering in the ongoing series on multisensor, multisource information fusion. We are glad to mark another milestone, namely we have so far published in these proceedings over 400 papers. As we have noted in prior editorials, we have modified the title over the years to reflect the broadening of the scope of the conference to include fusion of information not only from multiple traditional sensors but also from other nontraditional data sources. The expanded scope also includes fusion of information derived through multiple information extraction algorithmic processes. As the title indicates these proceedings are spread across the three key facets of developments in the field, namely, architectures, algorithms, and applications. In order to better reflect the ground truth, the sessions and their titles are redefined each year to represent the changing contents driven by the evolving research and development in the community. This year, the presentations have been grouped into the following five sessions:

- Image Level Issues and Applications

- Detection and Classification

- Surveillance and Tracking

- Applications

- Miscellaneous Topics

An innovation this year is a panel session on "Performance Evaluation for Impact Assessment Systems," A written report on the panel session will be published in due course either in the next year's issue of the conference proceedings or elsewhere as convenient.

In accordance with the traditions followed over the years at this conference, and in contrast to the general policy of post-conference publication of the proceedings at most SPIE conferences, we have worked hard to once again provide the printed proceedings on-site at the conference. This has not only served the purpose of rapid dissemination in print form of the most recent developments in this area but also helped in better understanding of the oral presentations. Incidentally, it also complements the prime archival journal in this field, Information Fusion, which because of its dependence on formal and rigorous peer reviews is a more drawn-out process along the timeline. Another benefit, of this procedure of making the proceedings available on-site at the time of the conference, is that it enables better quality control over the presentations by limiting the program to those that have the full manuscript ready and thereby ensuring a more mature presentation. Indeed this process resulted in a significant culling of the initial submissions. While this decrease represents the downside of the process, we remain confident of its upside, namely, better quality control. 
The international character of this conference is once again reflected, not only in the program committee, but also in the contents of the proceedings, which includes 26 papers from 10 countries (representing a significant doubling in the spread as compared to last year) spread over multiple continents: Australia, Canada, France, Germany, Ireland, Netherlands, South Korea, Ukraine, United Kingdom, and, obviously, the United States. We plan to continue this series in the coming year and look forward to your participation, hopefully in greater numbers and depending upon the state of global politics and economy from a wider geographical background and at a higher level. Further details regarding the call for papers and schedule for next year will be made available in due course on the Internet at SPIE (www.spie.org) as well as on my home page (http://belur.noip.com).

In accordance with our long held tradition, the variation in the size of these proceedings in terms of the number of papers offered under this series over the years is graphically illustrated below in Figure 1 to provide us with an introspective look at our performance over the years. While the presentations this year is on par with last year, the number of presentations is still down from our peaks attained earlier in the decade. Possible reasons for this include:

(a) multiplicity of conferences catering to the fusion topic across the globe, a distinct change from the scenario of uniqueness we had when this event was initiated 12 years back,

(b) perhaps a more significant one is the increasing overlap in terms of the scope with other conferences here itself at this Defense and Security Symposium at Orlando that do not impose our stringent requirement of full manuscripts well before the conference time. (It is far easier to put together an abstract than to complete writing a full manuscript).

(c) a third cause, we suspect, is international travel related hardships including meeting stringent visa requirements, economic and geopolitical realities, all of which continue to have a chilling impact on attendance in US.

It is therefore critical that all of us who are interested in the continued success of this annual event to maximize our efforts for next year to ensure continued viability of the conference in the future. Towards this end, we welcome from the conference participants and the readership of this proceedings on ways to rejuvenate the growth of this conference and broaden its appeal in the coming years. Those interested in active participation, perhaps in terms of joining the program committee and/or develop special sessions for the next year should contact me at fusion_consultant@yahoo.com as soon as possible (preferably by March 31, 2008). 
In closing, I am pleased to acknowledge the authors for choosing this avenue for publication of their contributions. I also would like to take this opportunity to thank the members of my program committee and the session chairs for their continued support. Thanks are also due to SPIE staff for their invaluable help in making this all possible.

\section{कायेन वाचा मनसेन्द्रियैर्वा बुध्यात्मनावा प्रकृते स्वभावात करोमि यद्यत सकलं परस्मे श्रीमन्नारायणायेति समर्पयामि}

"kaayena vaachaa manasendriyairvaa budhyaatmanaavaa prakR^ite svabhaavaat karomi yadyat sakalaM parasmai shriiman naaraayaNaayeti samarpayaami"
Be it with my body, or with my mind With words, or organs of any kind, With my intellect, or with my soul, Or by force of Nature pushing me to my goal, Whatever it is, with all these I do,

Oh! Supreme Lord! I surrender to you.

Wishing all of you a safe return journey

Belur V. Dasarathy, Ph. D, FIEEE Chairman http://belur.no-ip.com fusion_consultant@yahoo.com 


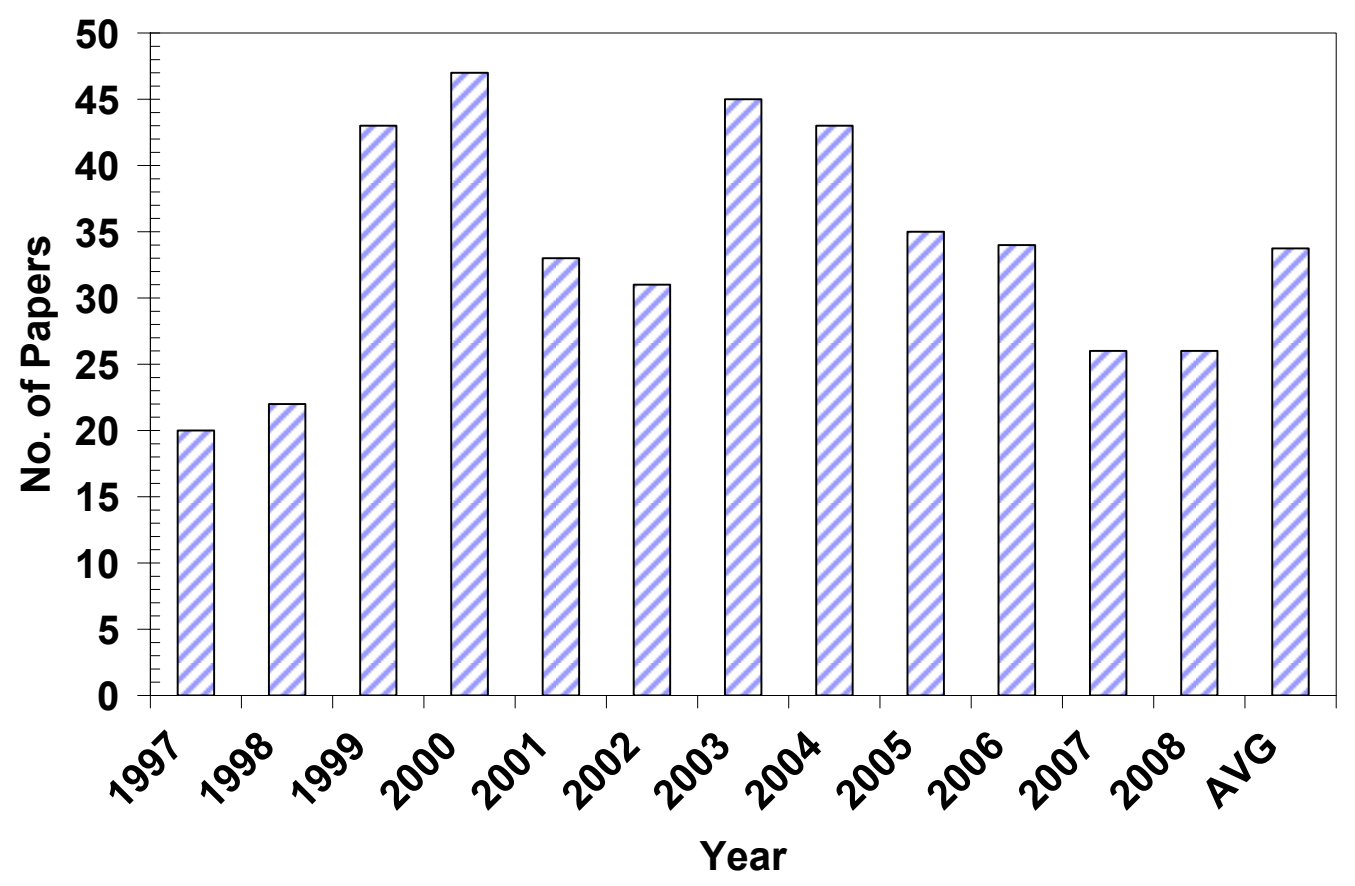

Figure 1. Number of papers published over the years in this series 